\title{
MECHANICAL AND CORROSION BEHAVIOUR OF IRON MODIFIED Cu-Zn-AI ALLOYS
}

Kenneth K. Alaneme ${ }^{l)}$ *, Ayoola A. Sulaimon ${ }^{l)}$, Peter A. Olubambi ${ }^{2)}$

${ }^{1)}$ Department of Metallurgical and Materials Engineering Federal University of Technology, Akure, PMB 704, Nigeria

${ }^{2)}$ Department of Chemical and Metallurgical Engineering, Tshwane University of Technology, Pretoria, South Africa

Received: 12.06 .2013

Accepted: 14.08.2013

"Corresponding author: e-mail: kalanemek@yahoo.co.uk, Tel.: +2348034228868, Department of Metallurgical and Materials Engineering, Federal University of Technology, Akure, PMB 704, Nigeria

\begin{abstract}
The mechanical and corrosion behaviour of iron modified $\mathrm{Cu}-\mathrm{Zn}-\mathrm{Al}$ alloys has been investigated. $\mathrm{Cu}-\mathrm{Zn}-\mathrm{Al}$ alloys containing 20 and $25 \mathrm{wt} \% \mathrm{Zn}$ was produced by casting method with and without the addition of $0.1 \mathrm{wt}$. \% iron. The alloys were subjected to a homogenization cold rolling- annealing treatment schedule, before the alloys were machined to specifications for tensile test, fracture toughness, hardness measurement, corrosion test and microstructural analysis. From the test results, it was observed that the structures of the $\mathrm{Cu}-\mathrm{Zn}-\mathrm{Al}$ alloys were modified by iron addition with near equi-axed grain morphologies developed. There was no significant difference in the hardness of the iron modified and the unmodified $\mathrm{Cu}-\mathrm{Zn}-\mathrm{Al}$ alloys, but the tensile strength, strain to fracture, and fracture toughness of the alloys improved with iron addition. The $\mathrm{Cu}-\mathrm{Zn}-\mathrm{Al}$ alloys also exhibited good corrosion resistance in $3.5 \mathrm{wt} \% \mathrm{NaCl}$ and $0.3 \mathrm{M} \mathrm{H}_{2} \mathrm{SO}_{4}$ solutions. It was however observed that irrespective of iron addition, the mechanical properties and corrosion resistance of the $\mathrm{Cu}-20 \mathrm{Zn}-4 \mathrm{Al}-\mathrm{xFe}$ alloy compositions where better in comparison with the $\mathrm{Cu}-25 \mathrm{Zn}-4 \mathrm{Al}-\mathrm{xFe}$ alloy grades (where $\mathrm{x}=0,0.1 \mathrm{wt}$. \%).
\end{abstract}

Keywords: $\mathrm{Cu}-\mathrm{Zn}-\mathrm{Al}$ shape memory alloys, shape memory properties, mechanical properties, corrosion behaviour, grain refinement

\section{Introduction}

The development of low cost metallic alloys involving good combination of shape memory capacity and material properties has continued to draw the attention of materials scientists [1]. Shape memory alloys (SMAs) are characterized by the capacity to recover its original shape after undergoing large deformation strains. The 'shape recovery' is usually triggered by heating (above a transition temperature) or stress removal. This unique material behaviour has made SMAs a very important class of metallic materials [2]. Shape memory properties such as pseudo elasticity, one way- and two way- shape memory effects [3] have served as the basis for the design of components/devices such as self actuating fasteners, heat-shrinkable couplings and switches, thermally actuated switches, thermostatic radiator valves, cooling fans for automobiles, thermal protection devises, and contact springs [4-5]. It has also been applied in the development of flexible glass frames, bra under wires, and many biomedical applications as a result of their 
good corrosion resistance and biocompatibility [6]. The high damping capacity of SMAs has made them suitable for applications where reduced noises and vibrations are required [7]. Thus considering the current areas of application of SMAs and its potential for wider use, it is expected that studies on how to improve their overall material properties will remain of interest in the years ahead.

The major setback in the development and application of SMAs remains that a substantial number of available low cost options do not exhibit satisfactory combination of mechanical and shape memory properties [8]. The most successful and commercially applied SMA, Ni-Ti, possesses very good strength, formability and shape memory properties but is very expensive to produce [9]. The relatively cheaper $\mathrm{Cu}$ based SMAs ( $\mathrm{Cu}-\mathrm{Zn}-\mathrm{Al}, \mathrm{Cu}-\mathrm{Al}-\mathrm{Ni}, \mathrm{Cu}-\mathrm{Al}-\mathrm{Mn}$ ) which are reported to be second to $\mathrm{Ni}-\mathrm{Ti}$ in terms of shape memory properties also have some limitations [9]. Most $\mathrm{Cu}$ based exhibit poor cold formability and tendency towards brittle fracture by virtue of their coarse grain structures. Also, they show a tendency to undergo natural ageing which affects its shape memory behaviour by raising the austenite/martensite transition temperature [10].The adoption of procedures to refine the grain structures of $\mathrm{Cu}$-based SMAs by thermomechanical treatment and the use of microelements such as Boron, Iron, Titanium among others has been projected to be the best option in improving its properties [10]. To date the results available are still not exhaustive, and considering that $\mathrm{Cu}$ based SMAs remains the most attractive long term option for replacing $\mathrm{Ni}-\mathrm{Ti}$ as a result of its relatively lower cost; research in $\mathrm{Cu}$ based SMAs will still continue to attract attention. In the present work, the influence of Iron addition on the microstructure, mechanical and corrosion behaviour of $\mathrm{Cu}-\mathrm{Zn}$ - $\mathrm{Al}$ alloy SMAs is investigated. $\mathrm{Cu}-\mathrm{Zn}-\mathrm{Al}$ alloys are developed from relatively cheap metals using conventional metallurgical processes and are the least costly commercial SMAs available]. They have been noted to offer modest shape memory properties and recoverable strain of about $5 \%$ [11] but still have the potentials for improved mechanical properties particularly strength - ductility levels and fracture toughness while maintaining its high corrosion resistance.

\section{Materials and Method}

\subsection{Alloy and Sample Preparation}

The $\mathrm{Cu}-25.5 \mathrm{Zn}-4.0 \mathrm{Al}$ and $\mathrm{Cu}-20 \mathrm{Zn}-4.0 \mathrm{Al}$ alloys (in wt \%) were initially produced without iron addition. The same alloys were produced with $0.1 \mathrm{wt} \%$ iron addition with the intention of minimizing grain growth and stabilizing the $\mathrm{Cu}-\mathrm{Zn}-\mathrm{Al}$ alloys microstructure [10]. Supplemental $2.5 \%$ Zinc was added during charge calculations to account for potential losses by evaporation during melting. The alloys were melted in a crucible furnace; and the melted alloys were cast into sand moulds inserted with metallic chills. The chemical composition of the $\mathrm{Cu}-\mathrm{Zn}$ - $\mathrm{Al}$ shape memory alloys determined by EDS analysis is presented in Table 1. After casting, the ingots with $25 \mathrm{~mm}$ diameter and $30 \mathrm{~cm}$ length, approximately, were homogenized at $800{ }^{\circ} \mathrm{C}$, for $4 \mathrm{~h}$ and then water quenched. The ingots were then cold-rolled (10\%, approximately), after which the alloys were annealed at $500^{\circ} \mathrm{C}$ for two hours followed by air cooling. The samples for tensile test, fracture toughness, hardness measurement, corrosion test, and microstructural analysis were then machined from the alloys. The machined samples were all subjected to a final annealing treatment at $500{ }^{\circ} \mathrm{C}$ for two hours before water quenching to remove stresses induced in them during the machining operation. 
Table 1 Chemical Composition of the $\mathrm{Cu}-\mathrm{Zn}-\mathrm{Al}$ alloys

\begin{tabular}{|l|l|l|l|l|}
\hline $\begin{array}{l}\text { Sample } \\
\text { Designation }\end{array}$ & $\mathrm{Cu}$ & $\mathrm{Zn}$ & $\mathrm{Al}$ & $\mathrm{Fe}$ \\
\hline $\mathrm{A} 1$ & 71.01 & 25.03 & 3.96 & - \\
\hline $\mathrm{A} 2$ & 70.91 & 25.03 & 3.96 & 0.1 \\
\hline $\mathrm{B} 1$ & 75.94 & 20.05 & 4.01 & - \\
\hline $\mathrm{B} 2$ & 75.84 & 20.05 & 4.01 & 0.1 \\
\hline
\end{tabular}

\subsection{Hardness Measurement}

The hardness of the $\mathrm{Cu}-\mathrm{Zn}$-Al alloys was determined using an EmcoTEST DURASCAN Microhardness Tester equipped with ecos Workflow ultra modern software. The samples for the hardness test were polished to obtain a flat and smooth surface finish before testing was conducted. A load of $100 \mathrm{~g}$ was applied on the specimens and the hardness was determined following standard procedures. Multiple hardness tests were performed on each sample and the mean of values within the range of $\pm 2 \%$ was taken as the hardness of the specimen.

\subsection{Tensile Testing}

The tensile strength and strain to fracture of the $\mathrm{Cu}-\mathrm{Zn}-\mathrm{Al}$ alloys were evaluated at room temperature with the aid of tensile testing performed in accordance with the ASTM 8M-91 standards [12]. The test was carried out using an Instron universal testing machine operated at a strain rate of $10^{-3} / \mathrm{s}$; and the samples for the test were machined to round specimen configuration with $6 \mathrm{~mm}$ diameter and $30 \mathrm{~mm}$ gauge length. Three repeat tests were performed for each $\mathrm{Cu}$ $\mathrm{Zn}-\mathrm{Al}$ composition to ensure repeatability and reliability of the data generated.

\subsection{Fracture Toughness Evaluation}

The fracture toughness of the $\mathrm{Cu}-\mathrm{Zn}-\mathrm{Al}$ alloys was evaluated using circumferential notch tensile (CNT) specimens [13]. The CNT testing was also performed at room temperature using an Instron universal testing machine. The samples for the test were machined having gauge length, specimen diameter (D), and notch diameter (d) of 30, 6, and 4.5 in $\mathrm{mm}$ respectively; and notch angle of $60^{\circ}$. The specimens were subjected to tensile loading to fracture and the fracture load $\left(\mathrm{P}_{\mathrm{f}}\right)$ obtained from the load - extension plots were used to evaluate the fracture toughness using the equation [14]:

$\mathrm{K}_{1 \mathrm{C}}=\mathrm{P}_{\mathrm{f}} /(\mathrm{D})^{3 / 2}[1.72(\mathrm{D} / \mathrm{d})-1.27]$

where, D and d are respectively the specimen diameter and the diameter of the notched section. Plane strain conditions and by extension, the validity of the fracture toughness values obtained was determined using the relations in accordance with Nath and Das [15]:

$\mathrm{D} \geq\left(\mathrm{K}_{1 \mathrm{C}} / \sigma_{\mathrm{y}}\right)^{2}$

Three repeat tests were performed for each $\mathrm{Cu}-\mathrm{Zn}$-Al composition to ensure repeatability and reliability of the data generated.

\subsection{Microstructural Analysis}

The microstructure of the $\mathrm{Cu}-\mathrm{Zn}-\mathrm{Al}$ alloy samples was observed using a Zeiss Metallurgical Microscope with accessories for image analysis. The samples were metallographically polished 
and etched with $5 \mathrm{~g}$ ferric chloride $+10 \mathrm{ml} \mathrm{HCl}+95 \mathrm{ml}$ ethanol solution before the microscopic examination. A JSM 7600F Jeol ultra-high resolution field emission gun scanning electron microscope (FEG-SEM) equipped with an EDS was also used for chemical compositional analysis and in-depth microstructural study of the alloys.

\subsection{Corrosion Test}

The corrosion behaviour of the $\mathrm{Cu}-\mathrm{Zn}-\mathrm{Al}$ alloys was studied using mass loss and corrosion rate measurements. The corrosion tests were performed by immersion of the $\mathrm{Cu}-\mathrm{Zn}-\mathrm{Al}$ alloy samples in $0.3 \mathrm{M} \mathrm{H}_{2} \mathrm{SO}_{4}$ and $3.5 \mathrm{wt} \% \mathrm{NaCl}$ solution were both prepared following standard procedures [16]. The $0.3 \mathrm{M} \mathrm{H}_{2} \mathrm{SO}_{4}$ and $3.5 \mathrm{wt} \% \mathrm{NaCl}$ solutions are both reported in literature as representative of acidic and marine environments which are among typical service environments where the $\mathrm{Cu}-\mathrm{Zn}-\mathrm{Al}$ alloys are utilized [17-18]. The specimens for the test were cut to size $10 \times 10 \times 10 \mathrm{~mm}$ and where mechanically polished with emery papers in order to produce a smooth surface finish. The samples were de-greased with acetone and then rinsed in distilled water before immersion both corrosion media. The solution-to-sample surface area ratio was about $150 \mathrm{ml} \mathrm{cm}^{-2}$, and the corrosion setups were exposed to atmospheric air for the duration of the corrosion test. Weight loss readings were monitored on two day intervals for a period of 40 days. The mass loss $\left(\mathrm{g} / \mathrm{cm}^{2}\right)$ and the corrosion rate $\left(\mathrm{mmy}^{-1}\right)$ for each sample was evaluated following recommendations in accordance with ASTM G31 standards [19].

\section{Results and Discussion}

\subsection{Microstructures of the $\mathrm{Cu}-\mathrm{Zn}$-Al Alloys}

Representative optical photomicrographs of all the $\mathrm{Cu}-\mathrm{Zn}-\mathrm{Al}$ alloys are presented in Fig. 1 and 2. The needle-like structure that characterizes the martensitic phase [9] is clearly visible in the unmodified $\mathrm{Cu}-\mathrm{Zn}-\mathrm{Al}$ alloy containing $25 \mathrm{wt} \% \mathrm{Zn}$ (A1) (Fig. 1a), while the iron modified grade of the same $\mathrm{Cu}-\mathrm{Zn}$-Al alloy composition (A2) shows a refined structure with near equi-axed grain morphology with little signs of the needle-like structure (Fig. 1b). Similar but less conspicuous modification in the grain structure is observed for the unmodified and iron modified $\mathrm{Cu}-\mathrm{Zn}-\mathrm{Al}$ alloys containing $20 \mathrm{wt} \% \mathrm{Zn}$ (Fig. 2). This is a clear indication that iron addition alters the grain morphology of the $\mathrm{Cu}-\mathrm{Zn}-\mathrm{Al}$ alloys. A similar structural modification which is characterized by grain refinement has been reported by the use of some other microelements notably Boron, Titanium, and Titanium-Boron additions [10]. However, Iron remains a very good candidate addition considering its lower cost and availability.

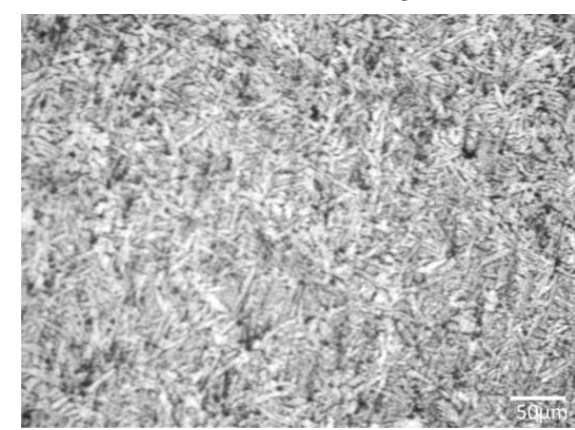

(a)

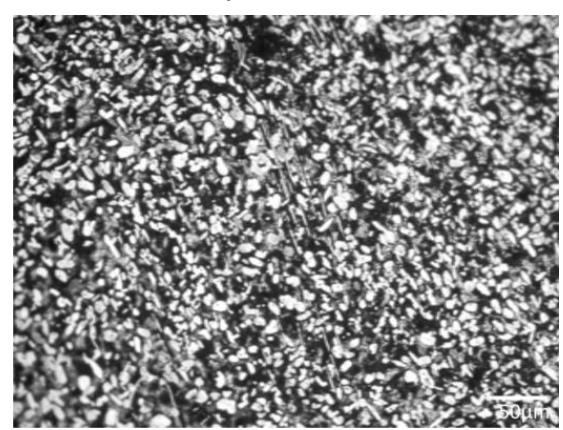

(b)

Fig. 1 Optical Micrograph of (a) unmodified $\mathrm{Cu}-25 \mathrm{Zn}-4 \mathrm{Al}$ alloy (A1) showing needle-like structures of the martensitic phase, and (b) iron modified $\mathrm{Cu}-25 \mathrm{Zn}-4 \mathrm{Al}-0.1 \mathrm{Fe}$ alloy (A2) showing near equi-axed grain structure. 


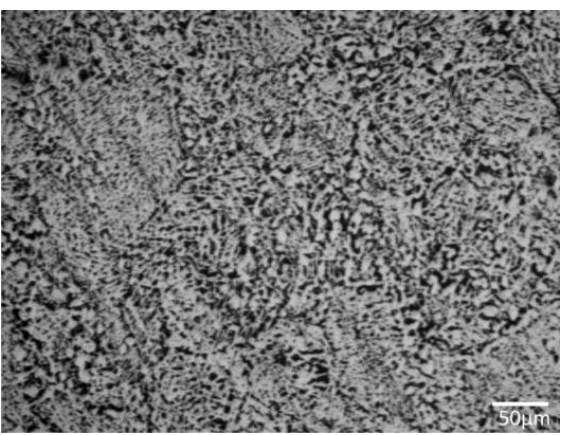

(a)

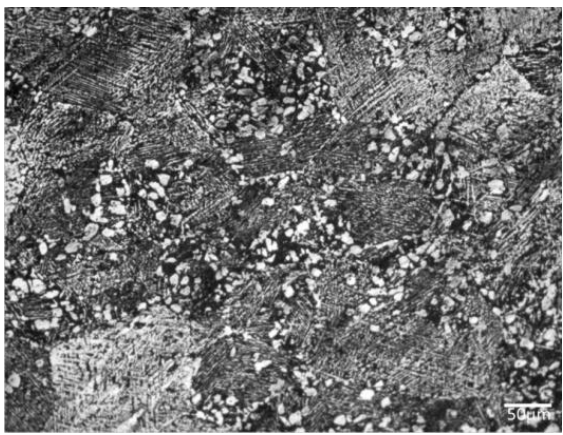

(b)

Fig. 2 Optical Micrograph of (a) unmodified Cu-20Zn-4Al alloy (B1), and (b) iron modified Cu-20Zn-4Al-0.1Fe alloy (B2).

\subsection{Mechanical Behaviour of the Cu-Zn-Al Alloys}

The hardness values of the $\mathrm{Cu}-\mathrm{Zn}-\mathrm{Al}$ alloys are presented in Fig. 3. It is observed that there is no significant difference in the hardness of the iron modified and the unmodified $\mathrm{Cu}-\mathrm{Zn}-\mathrm{Al}$ alloys, although the B series $\mathrm{Cu}-\mathrm{Zn}-\mathrm{Al}$ alloys containing $20 \mathrm{wt} \% \mathrm{Zn}$ exhibited slightly higher hardness values in comparison with the A series $\mathrm{Cu}-\mathrm{Zn}-\mathrm{Al}$ alloys containing $25 \mathrm{wt} \% \mathrm{Zn}$.

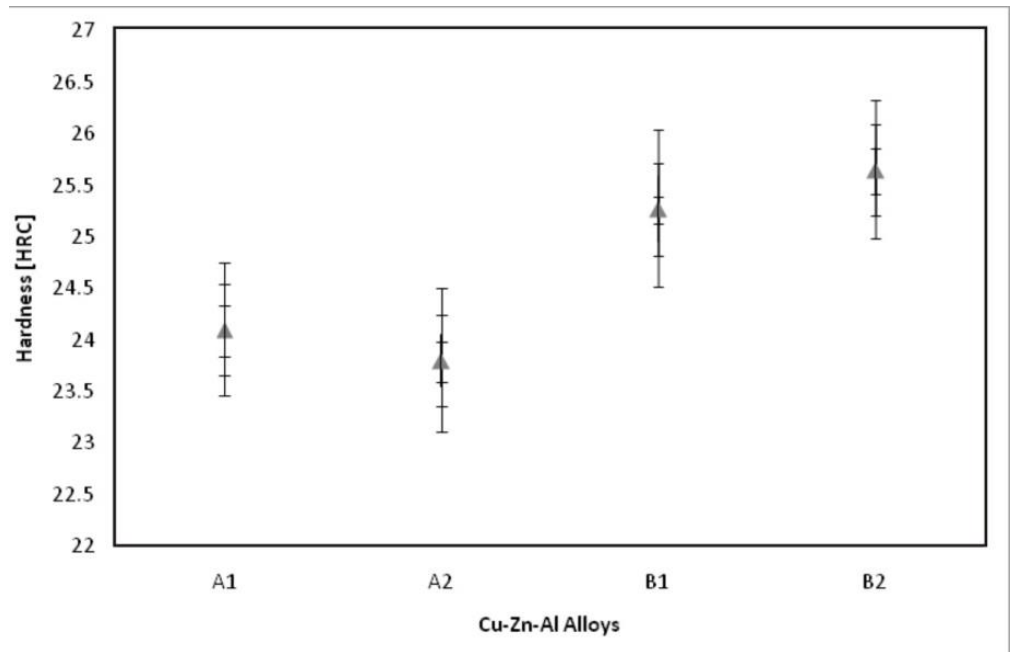

Fig. 3 Hardness values for the unmodified and iron added $\mathrm{Cu}-\mathrm{Zn}-\mathrm{Al}$ alloys.

The tensile strength (Fig. 4) is however observed to be lower for the unmodified alloys (A1, B1) in comparison with the iron modified samples (A2, B2). For the A series, it is observed that 3.72 $\%$ increase in tensile strength is achieved by iron modification while for the B series $3.43 \%$ increase in tensile strength was observed. The improved tensile of the iron modified $\mathrm{Cu}-\mathrm{Zn}-\mathrm{Al}$ alloys is attributed to its relatively refined grain structures (Fig. $1 \mathrm{~b}$ and $2 \mathrm{~b}$ ) which results in increased number of grain boundaries which serves as barriers to dislocation movement thus resulting in significant improvement in strength $[10,20]$. It is however noted that the $\mathrm{Cu}-\mathrm{Zn}-\mathrm{Al}$ alloys with $20 \mathrm{wt} \% \mathrm{Zn}$ (B series) had relatively higher tensile strength values in comparison with the A series $\mathrm{Cu}-\mathrm{Zn}-\mathrm{Al}$ alloys which had $25 \mathrm{wt} \%$ of $\mathrm{Zn}$. This is quite encouraging from an 
economic perspective as $\mathrm{Zn}$ is relatively the most expensive of the three elements used in the development of the $\mathrm{Cu}-\mathrm{Zn}$-Al ternary alloy system.

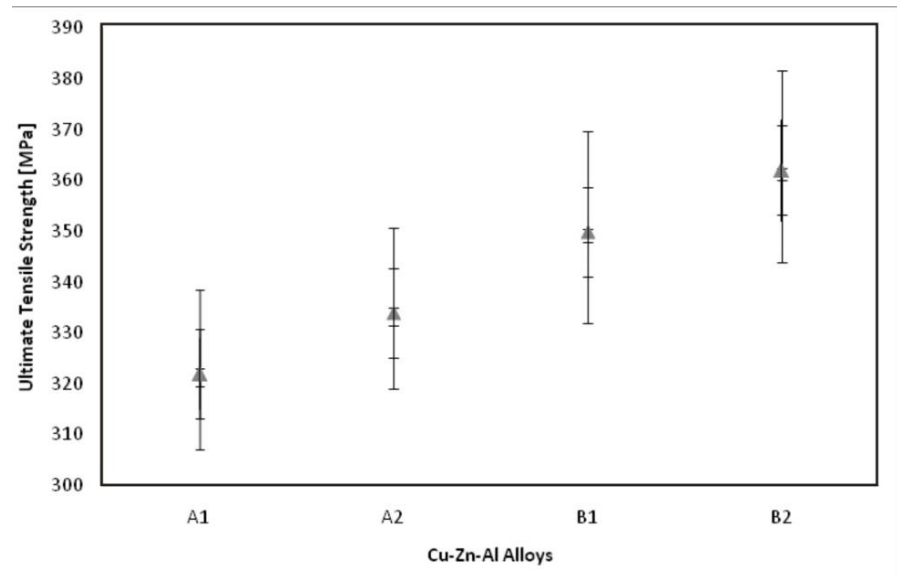

Fig. 4 Ultimate Tensile Strength values for the unmodified and iron added $\mathrm{Cu}-\mathrm{Zn}-\mathrm{Al}$ alloys.

The strain to fracture (Fig. 5) is also observed to improve with iron modification. Strain increments well over $25.5 \%$ for the unmodified Composition A and $18.5 \%$ for unmodified composition $\mathrm{B}$ was achieved with iron addition to the $\mathrm{Cu}-\mathrm{Zn}$ - $\mathrm{Al}$ alloys. This is a clear indicator that the capacity of $\mathrm{Cu}-\mathrm{Zn}-\mathrm{Al}$ alloys to sustain plastic deformation and by extension its cold workability, improves with iron modification.

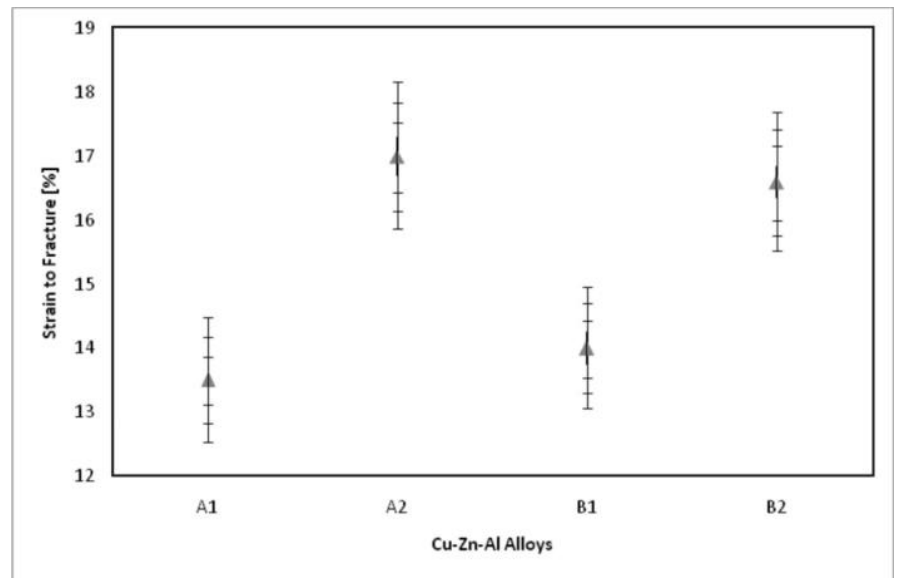

Fig. 5 Strain to Fracture values for the unmodified and iron added $\mathrm{Cu}-\mathrm{Zn}-\mathrm{Al}$ alloys.

The fracture toughness of the $\mathrm{Cu}-\mathrm{Zn}-\mathrm{Al}$ alloys is presented in Fig. 6. It is observed that the fracture toughness of the $\mathrm{Cu}-\mathrm{Zn}-\mathrm{Al}$ alloys increases with iron addition. $11.85 \%$ increase in fracture toughness was achieved for composition A while $13 \%$ increase was obtained for composition B with iron addition. This shows that there is improved capacity of the $\mathrm{Cu}-\mathrm{Zn}-\mathrm{Al}$ alloys to resist crack propagation by addition of iron into the alloy composition. This is due to the grain refining and stabilizing effect induced by iron addition on the $\mathrm{Cu}-\mathrm{Zn}-\mathrm{Al}$ alloys thereby increasing its toughness and hence resistance to crack propagation [10]. The SEM 
photomicrographs presented in Fig. 7 shows that the fracture mechanism of the $\mathrm{Cu}-\mathrm{Zn}-\mathrm{Al}$ alloys is ductile fracture as there are predominantly spherical dimples (which characterizes the fracture mode of ductile materials) observable from the fractured surface of the alloys [21].

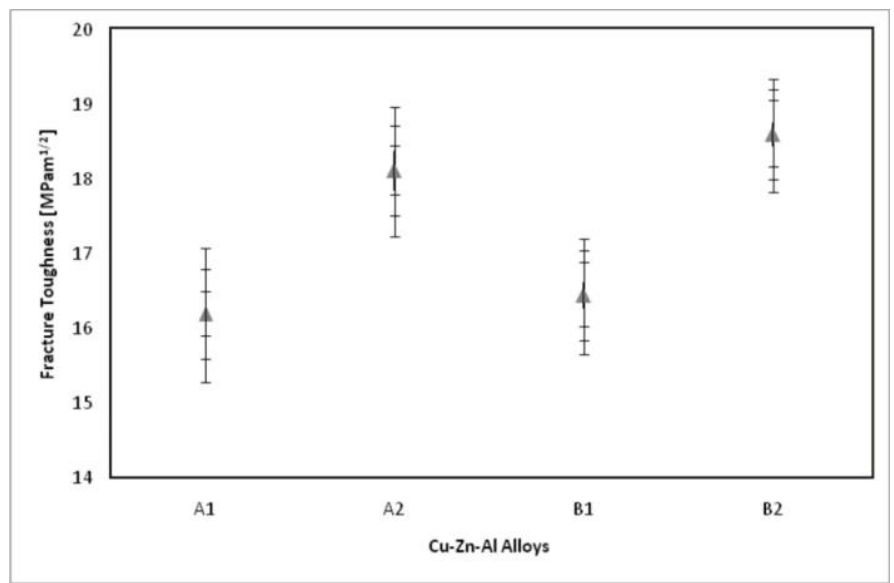

Fig. 6 Fracture Toughness values for the unmodified and iron added $\mathrm{Cu}-\mathrm{Zn}$ - $\mathrm{Al}$ alloys.

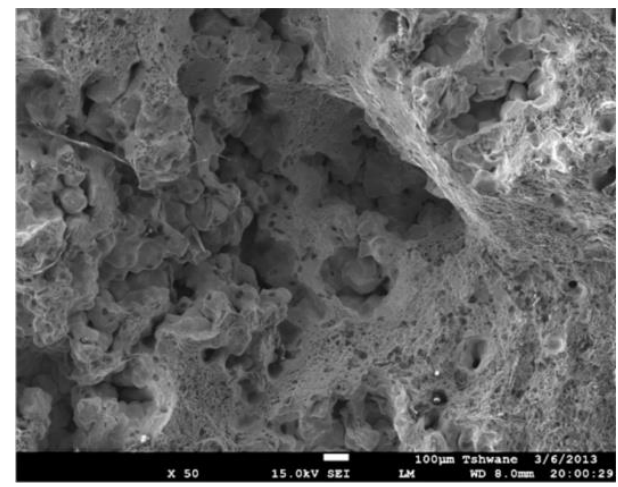

(a)

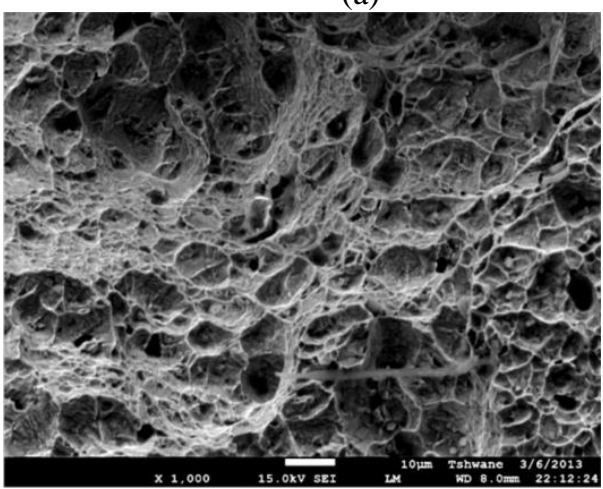

(c)

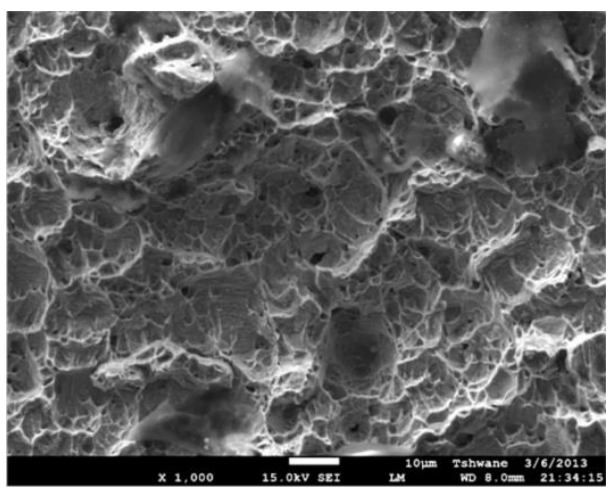

(b)

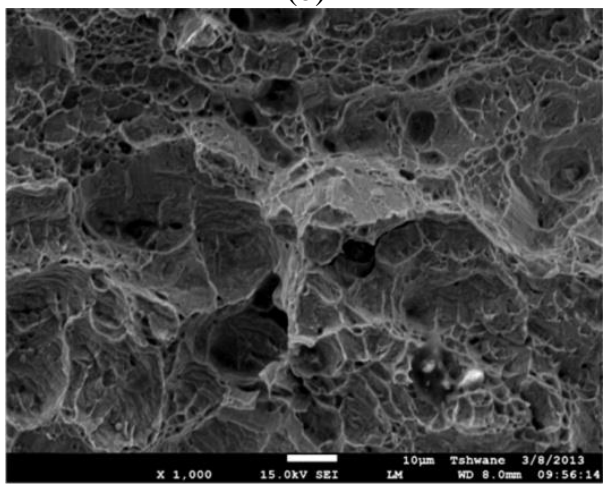

(d)

Fig. 7 SE image of the fracture surfaces of (a) unmodified $\mathrm{Cu}-25 \mathrm{Zn}-4 \mathrm{Al}$ alloy (A1), (b) iron modified $\mathrm{Cu}-25 \mathrm{Zn}-4 \mathrm{Al}$ alloy (A2), (c) unmodified $\mathrm{Cu}-20 \mathrm{Zn}-4 \mathrm{Al}$ alloy (B1), and (d) iron modified $\mathrm{Cu}-20 \mathrm{Zn}-4 \mathrm{Al}$ alloy (B2). 


\subsection{Corrosion behaviour of the $\mathrm{Cu}-\mathrm{Zn}-\mathrm{Al}$ alloys}

The variation of mass loss and corrosion rates for the $\mathrm{Cu}-\mathrm{Zn}-\mathrm{Al}$ alloys immersed in $3.5 \mathrm{wt} \%$ $\mathrm{NaCl}$ and $0.3 \mathrm{M} \mathrm{H}_{2} \mathrm{SO}_{4}$ solutions are presented in Figs. 8-9. From figure $8(\mathrm{a})$ it is observed that the mass loss of all the $\mathrm{Cu}-\mathrm{Zn}-\mathrm{Al}$ alloys were very low $\left(<0.0025 \mathrm{~g} / \mathrm{cm}^{2}\right)$. This is a good indication that the $\mathrm{Cu}-\mathrm{Zn}-\mathrm{Al}$ alloys can be used in the design of components for marine/saline environments. It is however noted that the corrosion trend fluctuates with exposure time as there appears to be a continuum of passive film formation, film breakdown, and repassivation as accounted for by the intermittent increase and decrease in mass loss of all the samples. It is also noted that Iron addition to the $\mathrm{Cu}-\mathrm{Zn}-\mathrm{Al}$ alloys (A2 and B2) did not increase the tendency for corrosion of the alloys in $3.5 \mathrm{wt} \% \mathrm{NaCl}$ solution. The corrosion rate plots, Figure 8(b), supports the observations from Figure $8(\mathrm{a})$ as it is seen that corrosion rates were very low (apart from the initial period of immersion). Similar high corrosion resistance has been reported for quenched $\mathrm{Cu}-\mathrm{Zn}-\mathrm{Al}$ alloys exposed to marine environments [17].

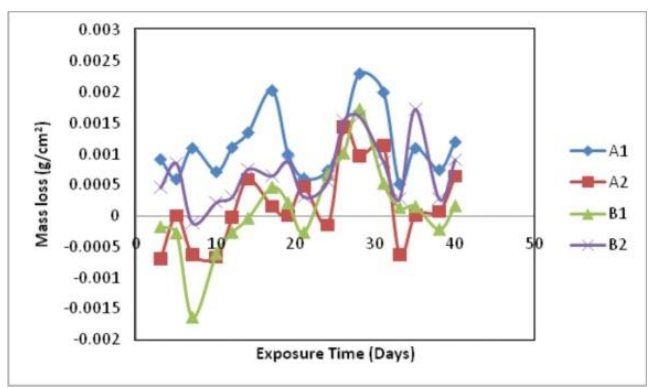

(a)

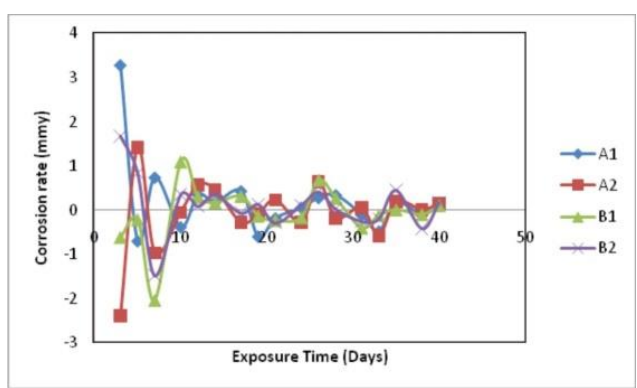

(b)

Fig. 8 showing (a) Mass loss for the unmodified and iron added $\mathrm{Cu}-\mathrm{Zn}-\mathrm{Al}$ alloys immersed in $3.5 \% \mathrm{NaCl}$ solution, and (b) Corrosion rate for the unmodified and iron added $\mathrm{Cu}-\mathrm{Zn}$ $\mathrm{Al}$ alloys immersed in $3.5 \% \mathrm{NaCl}$ solution.

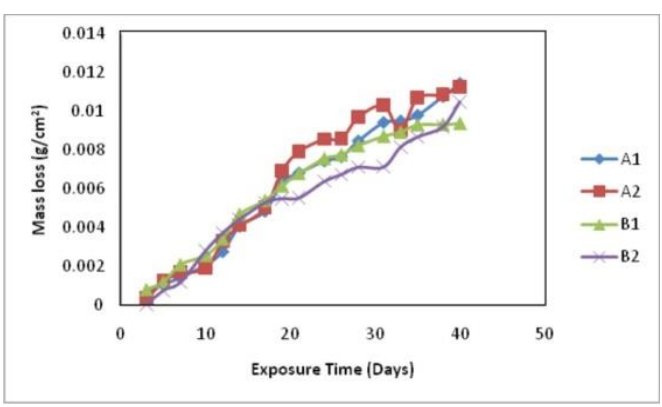

(a)

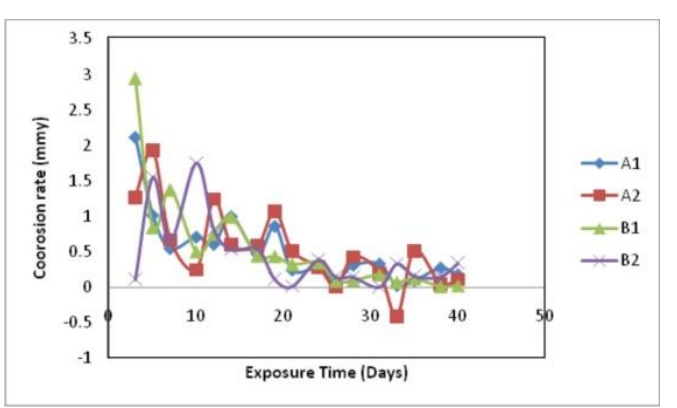

(b)

Fig. 9 showing (a) Mass loss for the unmodified and iron added $\mathrm{Cu}-\mathrm{Zn}-\mathrm{Al}$ alloys immersed in $0.3 \mathrm{M} \mathrm{H}_{2} \mathrm{SO}_{4}$ solution, and (b) Corrosion rate for the unmodified and iron added $\mathrm{Cu}-\mathrm{Zn}$ $\mathrm{Al}$ alloys immersed in $0.3 \mathrm{M} \mathrm{H}_{2} \mathrm{SO}_{4}$ solution.

From Fig. 9(a) it is observed that the mass loss of the $\mathrm{Cu}-\mathrm{Zn}-\mathrm{Al}$ alloys is low in $0.3 \mathrm{MH}_{2} \mathrm{SO}_{4}$ solution $\left(<0.012 \mathrm{~g} / \mathrm{cm}^{2}\right)$; which shows that the $\mathrm{Cu}-\mathrm{Zn}-\mathrm{Al}$ alloys has good corrosion resistance in sulphuric acid media and can be used in such environments. It is noted that the mass loss increases with exposure time although the rate decreases sharply with exposure time (Figure 9b). 
It has been reported that the addition of Aluminium to $\mathrm{Cu}$-based alloys is effective in improving the corrosion resistance when the alloys are exposed to a sulfide-containing or high temperature environments [18]. It is however observed from Figure 9(a) that the B series $\mathrm{Cu}-\mathrm{Zn}-\mathrm{Al}$ alloy composition (which has $20 \mathrm{wt} \% \mathrm{Zn}$ ) exhibited a relatively lower corrosion tendency but there appeared not to be adverse effect of iron addition on the corrosion behaviour.

\section{Conclusion}

The influence of iron addition on the microstructure, mechanical and corrosion behaviour of $\mathrm{Cu}$ $\mathrm{Zn}-\mathrm{Al}$ alloys was investigated. The results show that:

1. The structures of the $\mathrm{Cu}-\mathrm{Zn}-\mathrm{Al}$ alloys are modified with iron addition with near equi-axed grain morphologies developed.

2. There was no significant difference in the hardness of the iron modified and the unmodified $\mathrm{Cu}-\mathrm{Zn}-\mathrm{Al}$ alloys, the tensile strength, strain to fracture, and fracture toughness of the alloys improved with iron addition.

3. The $\mathrm{Cu}-\mathrm{Zn}-\mathrm{Al}$ alloys exhibited good corrosion resistance in $3.5 \mathrm{wt} \% \mathrm{NaCl}$ and $0.3 \mathrm{M} \mathrm{H}_{2} \mathrm{SO}_{4}$ solutions.

4. Irrespective of Iron addition, the mechanical properties and corrosion resistance of the $\mathrm{Cu}$ 20Zn-4Al-xFe alloy compositions where better in comparison with the $\mathrm{Cu}-25 \mathrm{Zn}-4 \mathrm{Al}-\mathrm{xFe}$ alloy grades (where $\mathrm{x}=0,0.1 \mathrm{wt}$ \%).

\section{References}

[1] K. Otsuka, C. M. Wayman (Eds.): Shape Memory Materials, Cambridge University Press, Cambridge, UK, 1998

[2] J. Van Humbeeck, J. Cederstrom: The present state of shape memory materials and barriers still to be overcome, The first international conference on shape memory and superelastic technologies, 1994, USA, p. 1-6

[3] G. Wei, R. Sandstrom, S. Miyazaki: Journal of Materials Science, Vol. 33, 1998, p. 37433762

[4] B. M. Rabeeh, M. M. El Batanouny, A. E. El Ashram: Canadian Journal on Mechanical Sciences and Engineering, Vol. 2, 2011, No. 2, p. 11-18

[5] J. Van Humbeeck: Materials Science and Engineering A, Vol. 273-275, 1999, p. 134-148, DOI: 10.1016/S0921-5093(99)00293-2

[6] L. Petrini, F. Migliavacca: Journal of Metallurgy, 2011, ID 501483, p. 15, DOI:10.1155/2011/501483

[7] N. Koeda, T. Omori, Y. Sutou, H. Suzuki, M. Wakita, R. Kainuma, K. Ishida: Materials Transactions, Vol. 46, 2005, No. 1, p. 118-122

[8] Y. Sutou, T. Omori, R. Kainuma, K. Ishida: Materials Science and Technology, Vol. 24, 2008, No. 8, p. 896-901

[9] V. Asanovic, K. Delijic: Journal of Metallurgy, Vol. 13, 2007, No. 5, p. 59-64

[10]R. A. Sanguinetti Ferreira et al.: Materials Research, Vol. 3, 2000, No. 4, p.119-123

[11] Hopulele, S. Istrate, S. Stanciu, Gh. Calugaru: Journal of Optoelectronics and Advanced Materials, Vol. 6, 2004, No. 1, p. 277-282

[12] ASTM G31 Standards: Metals Test Methods and Analytical Procedures, Vol. 3, Wear and Erosion; Metal Corrosion, Annual Book of ASTM Standards, Philadelphia, 1994

[13] K. K. Alaneme: Materials Research, Vol. 14, 2011, No.2, p. 155-160, DOI: 10.1590/S151614392011005000028 
[14] G. E. Dieter. Mechanical Metallurgy, McGraw-Hill, Singapore, 1988

[15] S. K. Nath, U. K. Das: Journal of Naval Architecture and Marine Engineering, Vol. 3, 2006, p. $15-22$

[16] K. K. Alaneme, B. O. Ademilua, M. O. Bodunrin: Tribology in Industry, Vol. 35, 2013, No. 1, p. $25-35$

[17] [03/05/2013] C. Rong-na: Effect of Heat Treatment on Corrosion Property of CuZnAl Alloy in $3.5 \% \mathrm{NaCl}$ Solution, Physics Examination and Testing, http;//en.cnki.com.cn/Articleen/CJFDTOTAL-WLCS200602003.htm

[18] H. H. Kuo, W. H. Wang, Y. F. Hsu, C. A. Huang: Corrosion Science, Vol. 48, 2006, p. 4352-4364

[19] ASTM G31 Standards: Metals Test Methods and Analytical Procedures, Vol. 3, Wear and Erosion; Metal Corrosion, Annual Book of ASTM Standards, Philadelphia, 1994.

[20] S. M. Al-Qawabah: Journal of Mechanical and Industrial Engineering, Vol. 6, 2012, No. 2, p. 175-181

[21] T. W. Courtney: Mechanical Behaviour of Materials, Second Edition, Overseas Press, India, 2006

\section{Acknowledgements}

Authors are grateful for the support of their respective Universities for creating an enabling research environment to embark on the experimental work. 